\title{
Review \\ A Sixty-Year Research and Development of Trichosanthin, a Ribosome-Inactivating Protein
}

\author{
Jia-Qi Lu ${ }^{1}$, Kam-Bo Wong ${ }^{1}$ and Pang-Chui Shaw ${ }^{1,2, *}$ \\ 1 Centre for Protein Science and Crystallography, School of Life Sciences, The Chinese University of Hong \\ Kong, Shatin, Hong Kong, China; lujq@link.cuhk.edu.hk (J.-Q.L.); kbwong@cuhk.edu.hk (K.-B.W.) \\ 2 Li Dak Sum Yip Yio Chin R\&D Centre for Chinese Medicine, The Chinese University of Hong Kong, Shatin, \\ Hong Kong, China \\ * Correspondence: pcshaw@cuhk.edu.hk
}

Citation: Lu, J.-Q.; Wong, K.-B.; Shaw, P.-C. A Sixty-Year Research and Development of Trichosanthin, a Ribosome-Inactivating Protein. Toxins 2022, 14, 178. https:// doi.org/10.3390/toxins14030178

Received: 10 February 2022 Accepted: 25 February 2022 Published: 27 February 2022

Publisher's Note: MDPI stays neutral with regard to jurisdictional claims in published maps and institutional affiliations.

Copyright: (c) 2022 by the authors. Licensee MDPI, Basel, Switzerland. This article is an open access article distributed under the terms and conditions of the Creative Commons Attribution (CC BY) license (https:/ / creativecommons.org/licenses/by/ $4.0 /)$.

\begin{abstract}
Tian Hua Fen, a herbal powder extract that contains trichosanthin (TCS), was used as an abortifacient in traditional Chinese medicine. In 1972, TCS was purified to alleviate the side effects. Because of its clinical applications, TCS became one of the most active research areas in the 1960s to the 1980s in China. These include obtaining the sequence information in the 1980s and the crystal structure in 1995. The replication block of TCS on human immunodeficiency virus in lymphocytes and macrophages was found in 1989 and started a new chapter of its development. Clinical studies were subsequently conducted. TCS was also found to have the potential for gastric and colorectal cancer treatment. Studies on its mechanism showed TCS acts as an rRNA N-glycosylase (EC 3.2.2.22) by hydrolyzing and depurinating A-4324 in $\alpha$-sarcin/ricin loop on $28 \mathrm{~S}$ rRNA of rat ribosome. Its interaction with acidic ribosomal stalk proteins was revealed in 2007, and its trafficking in mammalian cells was elucidated in the 2000s. The adverse drug reactions, such as inducing immune responses, short plasma half-life, and non-specificity, somehow became the obstacles to its usage. Immunotoxins, sequence modification, or coupling with polyethylene glycerol and dextran were developed to improve the pharmacological properties. TCS has nicely shown the scientific basis of traditional Chinese medicine and how its research and development have expanded the knowledge and applications of ribosome-inactivating proteins.
\end{abstract}

Keywords: Tian Hua Fen; trichosanthin; abortifacient; rRNA N-glycosylase; anti-HIV; anti-cancer; immunotoxin

Key Contribution: This review states a sixty-year history of the research and development of trichosanthin, which is one of the representatives of drug development, and illustrates the scientific basis of traditional Chinese medicine.

\section{Introduction}

Trichosanthin (TCS) is generated from the extract of the root tuber of Trichosanthes kirilowii (Gua Lou) from the family of Cucurbitaceae [1]. The root tuber has long been used in traditional Chinese medicine (TCM) as an abortifacient called Tian Hua Fen [2]. The traditional medical book Qianjin Yifang by Sun Simiao was the first recording of Tian Hua Fen in the 7th century. The others, including Taiping Royal Prescriptions by Wang Huaiyin and Compendium of Materia Medica by Li Shizhen have also recorded it in prescriptions to deal with abortion, abnormal menstruation, and retained placenta [3].

Ancient records show different plant resources of Tian Hua Fen. Records in Chongxiu Zhenghe Jingshi Zhenglei Beiyong Bencao show two Gua Lou from Hengzhou and Junzhou [4]. The latter was used as Tian Hua Fen for abortion. Le et al. offer over 30 types of Gua Lou used in China [5,6]. Some of them were misused. One of them is the root of T. cucumeroides (Ser.) Maxim (Wang Gua). Others such as T. cavaleriei Levl. (Chang Mao Gua) and T. hupehensis. C. Y. Cheng et C. Y. Yueh (Hu Bei Gua Lou) have more side effects such as 
nausea and vomiting. Gua Lou that produces TCS mainly comes from Boxian in Anhui, Anyang in Henan, Pudong in Shanghai, and Nantong in Jiangsu [3] (Figure 1). Harvest of Gua Lou was usually carried out in late autumn to early spring. The root was peeled, cut into slices, and soaked in water for 5 days. The water was changed every day. Tian Hua Fen was then extracted from the clarified and sun-dried white powder.

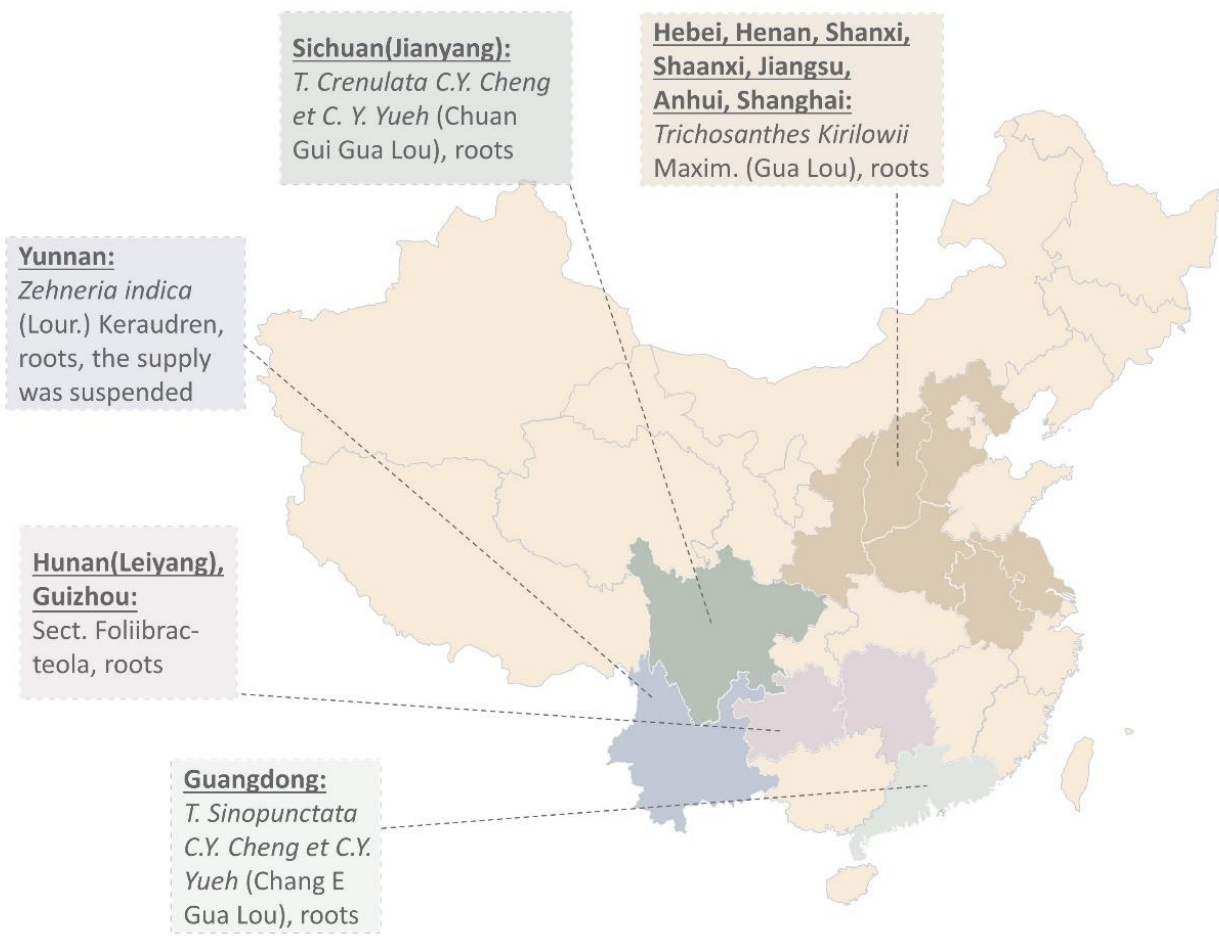

Figure 1. The sources of commercial Tian Hua Fen in China in the 1980s [3,7]. Researchers used the microscopic identification method to identify and authenticate commercial Tian Hua Fen in 21 provinces in China in the 1980s. The corresponding species names of their origins are shown on the map.

Monographs were published in 1990 [8] and 2000 [3] reviewing the efforts on TCS research in China and over the world. As with Artemisinin, the study on Tian Hua Fen represents drug development from traditional Chinese medicine (TCM) and illustrates the scientific basis of TCM. In this review, we look back to the sixty-year research and development of TCS as an abortifacient, rRNA N-glycosylase, anti-HIV and anti-cancer agents to reveal the fascination of TCS.

\section{Trichosanthin as an Abortifacient}

\subsection{From Ancient Prescriptions to Crystallized Protein Powder}

Because of the lack of western drugs, Tian Hua Fen was used extensively in China for inducing abortion in the 1960s [2]. The prescription contains Tian Hua Fen, dried sterile fruit of Gleditsia sinensis (Ya Zao), Asarum sieboldii (Xi Xin), the root of Euphorbia fischeriana (Lang Du) or with three more herbs, including Angelica dahurica (Bai Zhi), the root of Kaempferia galanga L. (Shan Nai), and the root of Nardostachys chinensis Batal (Gan Song).

The herbs were crushed to make a liquid extract as a medicated vaginal suppository (4) to induce abortion. However, because of severe adverse drug reactions (ADR) such as fever, tetter, and abdominal pain, studies on revising the prescription were carried out. In 1965, researchers in Wuhan and Nanjing, China, conducted thorough studies on the chemical, pharmacology, and clinical characteristics of the prescriptions to improve its pharmacological performance. The original prescriptions were simplified to contain only Tian Hua Fen and Ya Zao, called "Tian Zao He Ji" in powder form as capsules in the 
late 1960s [3,9,10]. Tian Hua Fen was also precipitated with methanol and ethanol and assembled with Ya Zao as capsules called "Tian Ya San" [3].

However, ADR was still a concern in its application. In 1966, researchers in Shanghai further isolated and purified components in Ya Zao and Tian Hua Fen. One death report in clinical application in 1969 alerted researchers again on the impact of ADR. The researchers showed that only Tian Hua Fen could induce abortion in pregnant mice, while Ya Zao only causes muscle festering. This suggests Tian Hua Fen was the component for abortifacient, while Ya Zao was only an enhancer, profiting from its surfactant characteristic [9]. The effects of Tian Hua Fen in ectopic pregnancy and chorionic epithelioma were also reported $[2,11,12]$.

Tian Hua Fen itself was precipitated and made as injections, first used in 1972. The dosage was $5 \mathrm{mg}$ per dose. It was then developed as more purified injections in 1975 with only $2 \mathrm{mg}$ per dose. In 1982, the precipitated powder was further crystallized in barbitone buffer and came out as the single protein powder of trichosanthin (TCS) [10]. The dosage of these developed injections was further lower to $1.2 \mathrm{mg}$ per dose [13], which won the second prize of the National Invention Award. The flowchart of three representative isolation and purification methods of TCS from Trichosanthes Kirilowii in different ways are shown in Figure 2, the SDS-PAGE gel photo of purified TCS is also demonstrated (Figure 2B).

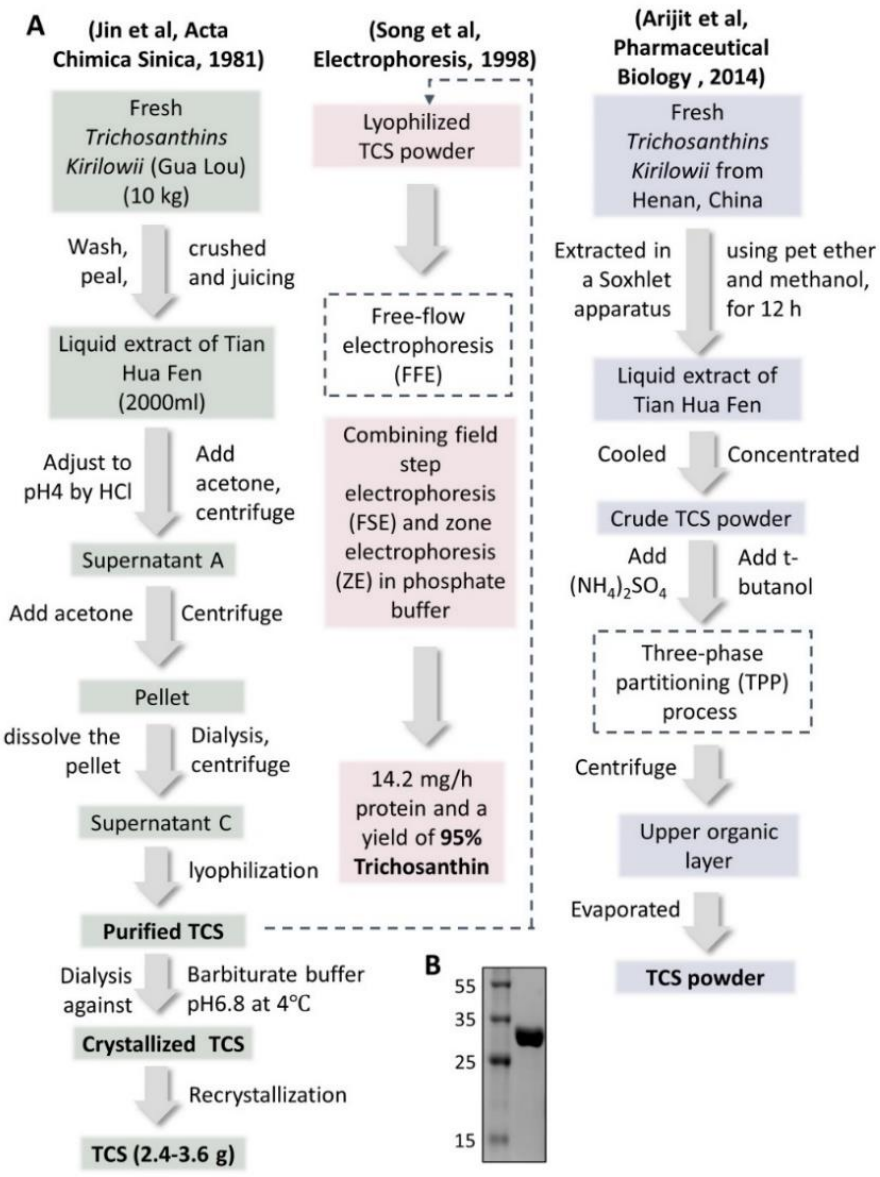

Figure 2. Extraction and purification steps of crystalized/purified TCS powder. (A) Three reported extraction and purification steps of TCS from Trichosanthes kirilowii are listed. Recrystallization [12], FFE (free-flow electrophoresis) [13] and TPP (three-phase partitioning) [14] processes were used. TCS: trichosanthin. (B) 15\% SDS-PAGE gel photo of purified TCS in our lab.

The clinical application was synergistically developed with its mechanism study. The mechanism on its midterm abortion and anti-early pregnancy effects were reported relying on the damage of syncytiotrophoblast cells [15] and the selective damage on chorionic tissue [16]. 


\subsection{Clinical Application of Tian Hua Fen or TCS as an Abortifacient}

The clinical studies of Tian Hua Fen and crystallized TCS powder were firstly on midterm abortion. They then expanded to anti-early pregnancy, ectopic pregnancy, molar pregnancy, and chorionic epithelioma. Tian Hua Fen was a topical medication for the vagina when used as a prescription for TCM. Then it was used for muscle, amniotic cavity, cervix uteri, or intrauterine injections with a simplified prescription and further purification (Table 1).

Table 1. Clinical studies using Trichosanthin (TCS).

\begin{tabular}{|c|c|c|c|c|c|c|}
\hline Time & Country/City & Agent & Target Disease & Effect & $\mathrm{ADR}^{1}$ & References \\
\hline $1989^{2}$ & $\mathrm{CA}, \mathrm{US}^{3}$ & GLQ223 $^{4}$ & AIDS & - & - & [17] \\
\hline 1990 & CA, US & GLQ223 & AIDS & $\begin{array}{l}\text { No consistent or } \\
\text { sustained changes }\end{array}$ & $\begin{array}{c}\text { No significant toxicity, except } \\
\text { one with a severe } \\
\text { neurological ADR. }\end{array}$ & [18] \\
\hline 1990 & $\begin{array}{l}\text { Nottingham, UK; } \\
\text { CA, US; FL, US }{ }^{6}\end{array}$ & $\begin{array}{l}\text { GLQ223 } \\
\text { (Phase I/II) }\end{array}$ & AIDS & $\begin{array}{l}\text { Serum p24 antigen decreased } \\
\text { after one month in } 10-18 \\
\text { patients; one converted to } \\
\text { negative. }\end{array}$ & $\begin{array}{l}\text { Severe fatigue and myalgias; } \\
\text { dementia or even coma in } \\
\text { two patients; one death }\end{array}$ & [19] \\
\hline 1990 & Shanghai, China & $\mathrm{TCS}^{7}$ & $\begin{array}{c}\text { Abortion } \\
\text { (10-14 weeks) }\end{array}$ & $\begin{array}{l}\text { High success rate, better in } \\
\text { cervical injections }\end{array}$ & $\begin{array}{l}\text { Increased body temperature; } \\
\text { pain at the injection site; } \\
\text { alleviated by dexamethasone }\end{array}$ & [11] \\
\hline 1991 & $\begin{array}{l}\text { CA, US; Pavia, } \\
\text { Italy }\end{array}$ & GLQ223 & AIDS & $\begin{array}{c}\text { Pharmacokinetic study; } \\
\text { predictability of elimination } \\
\text { and distribution among species }\end{array}$ & - & [20] \\
\hline 1991 & Shanghai, China & $\begin{array}{l}\text { TCS with } \\
\text { dexamethasone }\end{array}$ & $\begin{array}{l}\text { Midterm abortion } \\
\text { and anti-early } \\
\text { pregnancy }\end{array}$ & $\begin{array}{l}\text { High success rate } \\
\qquad(>83 \%)\end{array}$ & $\begin{array}{l}\text { Flu-like syndrome; can be } \\
\text { alleviated with } \\
\text { dexamethasone }\end{array}$ & [16] \\
\hline 1992 & Shanghai, China & TCS & AIDS & $\begin{array}{l}\text { Reduced p24 antigen, increased } \\
\text { CD4 cells }\end{array}$ & $\begin{array}{l}\text { Flu-like syndrome; pain and } \\
\text { erythema at the injection sites }\end{array}$ & [21] \\
\hline 1993 & $\begin{array}{l}\text { Nottingham, UK; } \\
\text { CA, US; MD, US }{ }^{8}\end{array}$ & GLQ223 & AIDS & - & $\begin{array}{l}\text { Two patients developed } \\
\text { coma; multifocal neurological } \\
\text { deficits after treatment. }\end{array}$ & [22] \\
\hline 1993 & CA, US; WA, US ${ }^{9}$ & GLQ223 & AIDS & $\begin{array}{c}\text { For patients who received } 36 \\
\text { and } 50 \mu \mathrm{g} / \mathrm{kg} \text {, an increase in } \\
\mathrm{CD} 4+\text { and CD } 8+\mathrm{T} \text { cells was } \\
\text { sustained; Beta-Microglobulin } \\
\text { levels increased during the } \\
\text { infusion. }\end{array}$ & $\begin{array}{l}\text { Flu-like syndrome with } \\
\text { muscle; joint aches; increase } \\
\text { in creatinine kinase levels }\end{array}$ & [23] \\
\hline 1994 & Shanghai, China & $\begin{array}{c}\text { TCS with } \\
\text { dexamethasone }\end{array}$ & Abortion & High success rate $(100 \%)$ & $\begin{array}{l}\text { Flu-like syndrome; alleviated } \\
\text { with dexamethasone }\end{array}$ & [24] \\
\hline 1994 & Shanghai, China & TCS & Abortion & - & $\begin{array}{l}\text { TCS may have a transient } \\
\text { effect on the myocardium }\end{array}$ & [25] \\
\hline 1994 & Nottingham, UK & $\begin{array}{l}\text { GLQ223 combined } \\
\text { with zidovudine }\end{array}$ & AIDS & $\begin{array}{l}\text { Significant increase in } \mathrm{CD}^{+} \text {cell } \\
\text { levels }\end{array}$ & $\begin{array}{c}\text { Myalgias, fevers, mild } \\
\text { elevation in liver function } \\
\text { tests; mild-moderate } \\
\text { anaphylactic reactions; two } \\
\text { with mental status changes }\end{array}$ & [26] \\
\hline 2000 & Shanghai, China & TCS & Tubal pregnancy & $92 \%$ success rate & Flu-like syndrome & [27] \\
\hline 2001 & Shanghai, China & TCS & Midterm abortion & High success rate $(98 \%)$ & Flu-like syndrome & [28] \\
\hline
\end{tabular}

${ }^{1}$ ADR: adverse drug reactions. ${ }^{2}$ 1989: a clinical trial in 1989 was halted in August by FDA, and then resumed with full FDA approval with a new design to evaluate the safety and effectiveness of GLQ223 over a longer term in San Francisco, Los Angeles, Miami, and Florida. ${ }^{3}$ CA, US: California, USA. ${ }^{4}$ GLQ223: also called Compound Q a highly purified, formulated form of TCS. ${ }^{5}$ Serum concentration of GLQ223 was around effective concentration in vitro but has not been maintained for a sufficient duration. ${ }^{6} \mathrm{Fl}$, US: Florida, USA. ${ }^{7}$ TCS: trichosanthin, purified protein from Trichosanthes kirilowii. ${ }^{8}$ MD, US: Maryland, USA. ${ }^{9}$ WA, US: Washington, DC, USA.

For midterm abortion, gravidas in 12-24 weeks pregnancy were treated with injections after a skin test [2]. The abortion occurred within seven days. ADR of Tian Hua Fen includes whole-body flu-like response (fever, headache, arthralgia, pharyngalgia, etc.), tetter, pain in the injection area, gingival and nose bleeding, abdominal pain, infection, severe allergic reactions, and massive hemorrhage [29]. To avoid these ADR, dexamethasone was used to alleviate side effects and prevent anaphylaxis [16]. According to a long-term follow-up on 528 patients, the midterm abortion by Tian Hua Fen did not show a notable impact on their health, menstruation, and fertility, nor on the development and intelligence of next generations.

Tian Hua Fen was also used in stopping early pregnancy [30]. As with midterm abortion, gravidas, within 12 weeks of pregnancy, were treated with injections after a skin 
test. The abortion occurs within two weeks. Flu-like symptoms were also the principal ADR. Nowadays, medical abortions mainly rely on hormones such as mifepristone and misoprostol, which show higher success rates and fewer side effects [31].

\subsection{Protein and DNA Sequences of TCS}

The primary structure (protein sequence) of TCS was first reported in the Symposium on the Organic Chemistry of Medicinal Natural Products held by the International Union of Pure and Applied Chemistry (IUPAC) in Shanghai in 1985 [32]. Wang et al. reported the TCS consists of 233 amino acids. In 1990, Collins et al. reported a slightly different sequence that consists of 247 (246) amino acids [33], which was later corroborated by Wang et al. [34]. The C-terminus of TCS has microheterogeneity, proved by the ESI-MS method [3]. Two peptides from the C-terminal of TCS were found ending at Ala and Met [35]. Multiple sequence alignment of TCS with other RIPs such as Karasurin, luffin, $\alpha-M M C$, and PAP shows several conserved amino acids.

Our group prepared the cDNA library of the root tuber of T. kirilowii, and cloned and sequenced the cDNA of TCS [36]. Recombinant TCS was then synthesized in E. coli [37]. This opened the door for using site-directed mutagenesis to study the molecular mechanism of TCS. Figure 3 shows the primary and nucleotide sequences of TCS. The multiple sequence alignments of TCS and other RIPs are also presented (Supplementary Figure S1). The mature TCS protein has 247 amino acids (aa), while the Pre-TCS contains a signal peptide (UniProt entry Q8LPV7/Q41611, 270 aa) and an extra region at C-terminus (UniProt entry Q41216/ Q84SV8, 289 aa) (Figure 3).

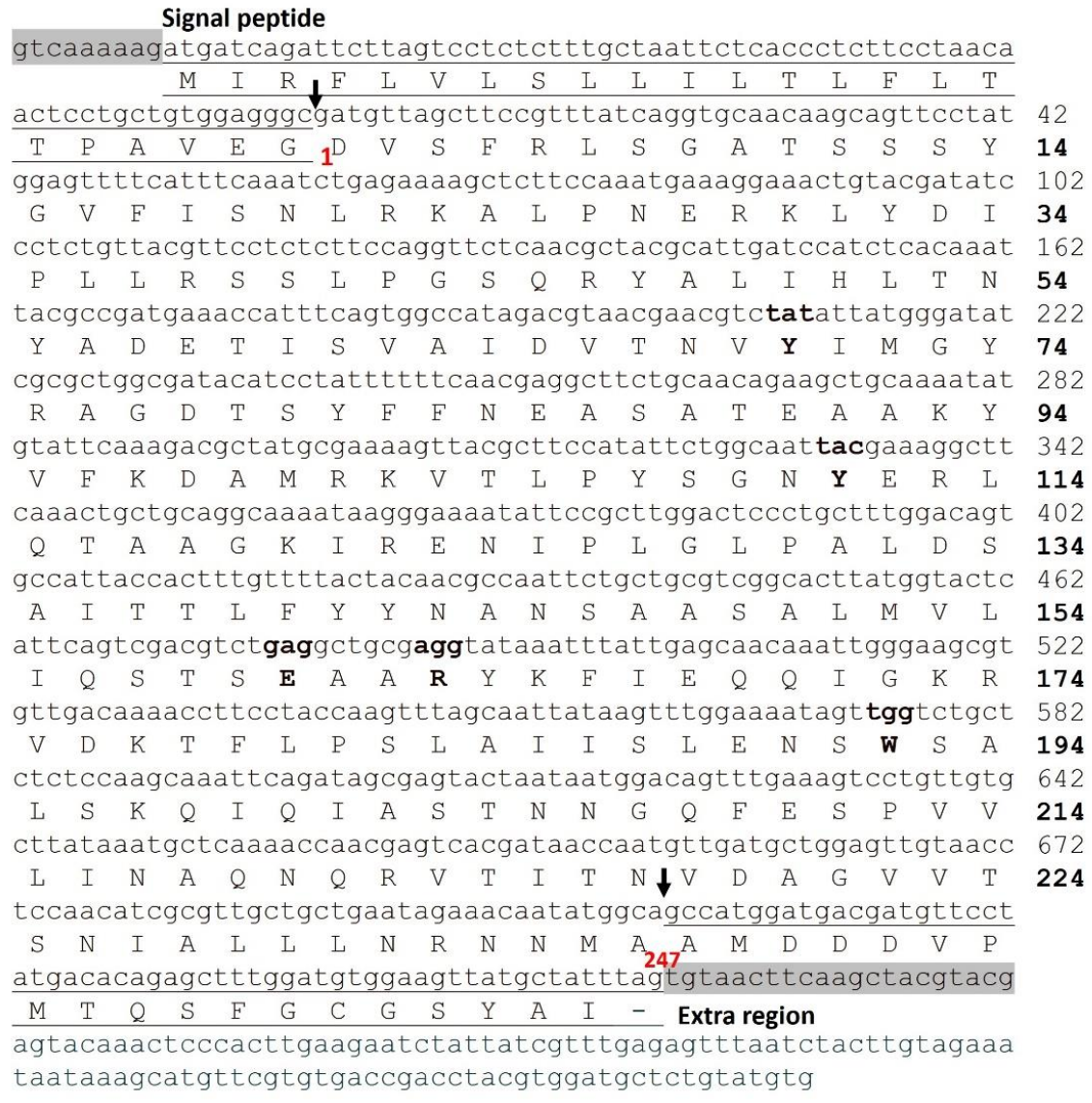

Figure 3. The DNA and protein sequences of TCS. The primary and nucleotide sequences of TCS (UniProt accession: Q6BBQ4; GenBank: M34858.1). The amino acids in the active centre are marked in bold. The signal peptide (-23--1 aa) at $\mathrm{N}$-termini and extra region (248-266 aa) at C-termini are underlined. 


\section{Trichosanthin as an rRNA N-glycosylase}

\subsection{Mechanism of TCS as an rRNA N-glycosylase}

Trichosanthin was shown to be an rRNA N-glycosylase (EC 3.2.2.22) in 1992 and was classified as a ribosome-inactivating protein (RIP) [38]. As with ricin [39], TCS catalyzes the hydrolysis of the $\mathrm{N}$-glycosidic bond of A-4324 on the conserved sarcin-ricin loop (SRL) on the 28S rRNA of rat ribosome [38].

RIPs have substrate specificity. Taking the ricin A chain (RTA) as an example, RTA cannot depurinate intact ribosomes from $E$. coli but can react on naked $23 \mathrm{~S}$ rRNA. Sequences of the 28S and 23S rRNA in $\alpha$-SRL are highly conserved. Endo et al. showed that ricin can retain its specificity mimic $\alpha$-SRL on 35-mer synthetic oligoribonucleotide [40], which confirmed the importance of this loop on the depurination activity of RIPs.

Depurination of the SRL inhibited the binding of the elongation factors to the ribosomes and suppressed the activation of GTPase [41-43]. In 2010, Voorhees et al. reported that SRL is located next to the translation GTPase binding site and directly modulates hydrolysis activation [44]. SRL exhibits conformational changes after depurination by RIPs, inhibiting the activation of GTP hydrolysis.

\subsection{Mechanism of TCS as Revealed by Structural Studies}

In the 1990s, crystal structures of TCS and other RIPs together with their substrates or analogues, including Formycin $5^{\prime}$-monophosphate (FMP), adenyl $\left(3^{\prime} \rightarrow 5^{\prime}\right)$ guanosine (ApG), ATP, adenosine (ADO), cytine monophosphate (CMP), tubercidin (Tub), and NADPH, were studied [45-48], providing the structural information of the catalytic centre and the foundation of mechanism study $[49,50]$. The detailed geometries of the active centers of TCS and other RIPs such as $\alpha$-momorcharin (MMC) are described and compared [46]. Only adenine molecules remained in the active centre in most crystal structures with the above substrates or analogues, suggesting the depurination reactions were already completed.

The structure of TCS (Figure 4a) consists of a large N-terminal domain with six alphahelices, a six-stranded sheet, an antiparallel beta-sheet, and a small C-terminal domain with the largest distinct bent alpha-helix (Figure 4a) [51]. There is a cleft between which is also located the conserved domain of RIPs (Supplementary Figure S1). This cleft was conjectured as the active cleft, which was confirmed by mutagenesis studies in the 1990s [52-54]. In the active center, Tyr70, Tyr111, Glu160, Arg163, and Phe192 are important in their activity and interaction with adenine (Figure 4b) [50]. Ile71 and Gly109 form hydrogen bonds with N(1) and N(6) of the adenine molecule in the active site $[54,55]$. The structural comparison of TCS with other RIPs was conducted recently [56].

In the proposed mechanism [1,36,37], the adenine ring of A- 4324 of $28 \mathrm{~S}$ rRNA is protonated by Arg 163. This attracts the electron flow from the ribose oxygen to the ring that breaks the N-glycosidic bond. The resulting oxocarbenium intermediate is stabilized by Glu 160 and is used to stabilize the oxocarbenium, further enhancing reaction rates. The regeneration of the rRNA $\mathrm{N}$-glycosylase is contributed from the subsequent nucleophilic attack of $\mathrm{C}-1$ of the water molecule to the ribose.

\subsection{Interaction of TCS with the Ribosome and the Recruitment by Ribosomal P-Protein}

TCS interacts with ribosomal stalk P-proteins and L10a [57,58]. Ribosomal P-proteins, including uL10 (previously known as P0 [59]), two P1, and P2, have highly conserved acidic sequences in the C-termini [58]. The two dimers of the stalk are arranged in parallel and interact respectively with uL10 [60]. Through chemical shift perturbation and mutagenesis analyses, the interaction with acidic ribosomal stalk proteins was found to help TCS to locate its RNA substrate [61]. This depurinated ribosome could not bind the elongation factors, thereby inhibiting the protein synthesis [61]. Ribosomes with depurinated SRL can also be a signal for halting the cell cycle [62].

In 2009, the co-crystallization of this C-terminal 11 amino acids peptide (C11-P) and TCS revealed the binding mode (Figure 4c). The ribosomal proteins interact with TCS at antiparallel $\beta$-sheet 9 and 10 with charge-charge interaction and hydrophobic bonds [63]. 
In 2013, Lee et al. showed the flexible C-terminal tails of P1/P2 heterodimer could reach up to $\sim 12.5 \mathrm{~nm}$ from the ribosomal stalk to recruit elongation factors or RIPs to the ribosomes [64-66]. The multiplication of P-proteins was found to contribute to the fidelity of translation [67], and multiple P-proteins also accelerated the interaction of RIPs and ribosome [68]. In 2017, Grela et al. showed functional non-equivalence of the individual P-protein CTDs [69]. In 2021, Horbowicz-Drożdżal et al. revealed that phosphorylation of the conserved C-terminal domain of ribosomal P-proteins impairs the interaction with plant toxins [70]. The study of how TCS interacts with ribosomes became a model for similar work in other RIPs [71].

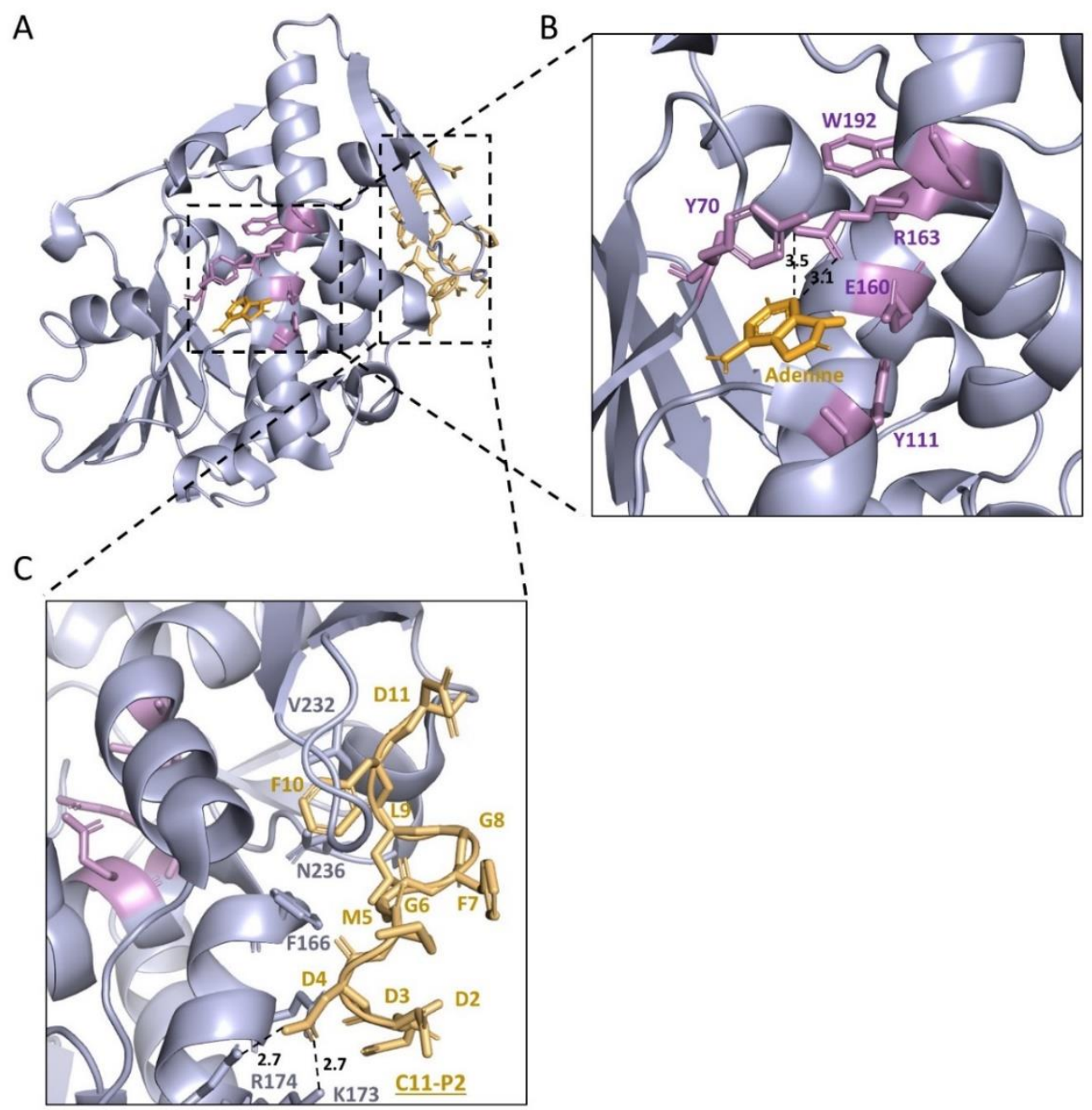

Figure 4. Structure basis of TCS as an rRNA N-glycosylase (EC 3.2.2.22). The structure of TCS with P2 (PDB code: 2JDL) was combined with the structure of TCS and adenine (PDB code: 1MRJ). (A) The protein structure of TCS is shown in a light blue image. (B) The active centre of TCS (Y70, Y111, E160, R163, W192) is shown in violet sticks. The active centre of TCS is conserved in RIPs. Adenine molecule is shown as bright orange sticks. Dash lines indicate hydrogen bonds between adenine molecule and TCS, and related distances $(\AA)$ are marked. The two tyrosine residues are stacking with adenine. (C) Interaction of TCS and C11-P2. C11-P2 (DDDMGFGLFD) is shown in light orange. C11-P2 interacts with the C-termini of TCS. Hydrogen bonds between C11-P2 peptide and TCS are shown in dash lines, and related distances $(\AA)$ are marked. RIPs: Ribosome-inactivating protein; TCS: trichosanthin; C11-P2: 11 amino acids of P2 protein in the C-termini (only ten amino acids are shown in the figure). 


\section{Trichosanthin as an Anti-HIV Agent}

\subsection{Anti-HIV Activity of TCS and Its Related Mechanism}

In 1989, McGrath et al. first reported the inhibitory activity of TCS on HIV replication in HIV-sensitive T-lymphoblastoid cells (VB cell line) [72,73]. Highly purified, formulated preparation of TCS, GLQ223 selectively reduced HIV p24 level. In 1991, Ferrari et al. used HIV-infected MT4, H9, and CEM-ss cells to evaluate the anti-HIV activity of TCS [74]. TCS inhibited syncytium formation in injected H9 cells and uninfected Sup-T1 cells from 0.5 to $4 \mu \mathrm{g} / \mathrm{mL}$. The HIV replication in infected H9 and CEL-ss cells can also be inhibited at $0.25 \mu \mathrm{g} / \mathrm{mL}$. A similar anti-HIV activity was also detected in primary cultures of monocyte/macrophages chronically infected with HIV [73].

The mechanism of the anti-HIV activity of TCS is not entirely clear. However, its rRNA $N$-glycosylase activity and enhancement of chemokines to stimulate chemotaxis and activation of pertussis toxin-sensitive G protein were considered the most important [75]. In recent decades, RIPs were reported to affect various processes in the life cycle of HIV, such as reverse transcription, integration, replication, and assembly [76].

Temporary interaction of TCS with HIV-1 long-terminal repeats (LTRs) can affect the HIV integration step [77]. TCS-enriched virions have HIV-1 scaffold protein Gag and lipid raft membrane, which can inhibit the infection ability of HIV [78]. Nicking endonuclease activity and DNase-like activity of TCS on DNA are also possible mechanisms [79]. Wang et al. raised that the anti-HIV activity of TCS may also be indispensable with its RIPs activity. The exceptions were TCS variants TCS-C19aa (19 amino acids C-terminal extension) and TCS-KDEL (signal sequence at C-terminal) [80]. These two variants retained all ribosomeinactivating (RI) activity but subsequently lost most of the anti-HIV-1 activity. The anti-HIV activity of TCS was also reported related to the MAPK signal pathway [81,82].

Lendray et al. in 1991 reported the treatment of GLQ223 on Simian immunodeficiency virus (SIV)-infected rhesus macaques [3]. Three SIV-infected rhesus macaques with detectable SIV, systemic lymphadenopathy, and decreased CD4/CD8 were treated with TCS at $200 \mu \mathrm{g} / \mathrm{kg} 1-2$ times a week by intravenous infusion (i.v.). ADR included flushing of the face, tremor, less physical activity and appetite, reversible and transient decreases of serum glutamic oxaloacetic transaminase (SGOT), serum glutamic pyruvic transaminase (SGPT), and lactate dehydrogenase (LDH). The experiment was suspended for one rhesus macaque because of the allergy. The second developed severe SIV diseases, and the third showed significantly longer survival.

\subsection{Clinical Study of TCS on AIDS Patients}

In the 1990s, after McGrath et al. reported the anti-HIV potential of TCS, the Food and Drug Administration (FDA) permitted the clinical study of TCS on HIV using purified and formulated preparation GLQ223 [18,83]. Unofficial clinical trials were also conducted using Shanghai Jinshan Pharmaceutical Factory injections. In addition, more than 1000 patients also tried treatment with TCS voluntarily in China.

For the Phase I clinical study, increasing dosages of TCS were used to measure the kinetic parameters such as biological half-life time $(\mathrm{t} 1 / 2)$, serum clearance rate, distribution, and ADR observation [18,20,23,83]. For medium or lower dosages $(1,8 \mu \mathrm{g} / \mathrm{kg})$, the dosages were well tolerated. For higher dosages $(16,24,36 \mu \mathrm{g} / \mathrm{kg}), 12$ patients complained of flu-like symptoms. One patient showed severe neurological symptoms with semiconscious, prostration, and internuclear ophthalmoplegia [23]. Higher dosages and longer i.v. time were then carried out in trials by Ciesielka et al., which showed a tolerance to $500 \mu \mathrm{g} / \mathrm{kg}$ in patients with TCS antibodies developed [3].

Phase II clinical trials were conducted in azidothymidine (AZT)-invalid HIV patients [19,84-87]. Results showed that combining TCS and other treatments such as AZT was a promising method $[19,87]$. Byers et al. in 1991 reported a clinical study with 112 patients using the dosage of $1.2 \mathrm{mg} /$ week for two weeks and following with one injection of TCS per month in combination with AZT and Didanosine (DDI). Results showed TCS could be used for synergistic treatment and reverse the CD4 T cells decrease $[19,87]$. However, 
a higher dosage was needed to further inhibit HIV replication [3]. The following phase II study of the addition of trichosanthin to zidovudine in patients with HIV disease and failing antiretroviral agents from the same research group [26] showed similar results. Nevertheless, none of the above studies were double-blind controlled, affecting the reliability. PEGylation modification [88] and immunotoxin (ITs) [89] were made to improve the pharmacological properties of TCS, as elaborated in the latter section (Section 6).

The clinical studies of TCS are listed in Table 1. TCS showed potential in HIV treatment. However, the side effects, including flu-like symptoms and reversible mental status changes, including dementia and even coma [76], hindered its further applications. Currently, cocktails-high active antiretroviral therapy is used for most AIDS treatments [90].

\section{Trichosanthin as an Anti-Cancer Agent}

\subsection{The Entering of TCS into Cells}

Trafficking of RIPs into the cells and interacting with ribosomes are essential steps for their cytotoxicity [91]. TCS is a Type I RIP, consisting of a single chain polypeptide with enzymatic activity. Type II RIPs such as ricin and abrin have a lectin binding B chain linked with the enzymatic A chain by disulfate bonds. In 1976, Sandvig et al. first reported the kinetics parameters of binding the lectin B chain of type II RIPs ricin and abrin to the human surface receptors [92]. In recent decades, lots of studies have revealed the mechanism [93].

Without the assistance of the lectin B chain, TCS uses receptor-mediated endocytosis and non-specific entry to enter the cells [51]. In 2003, Zhang et al. reported that the seven amino acids in the C-termini mimic the function of the lectin binding domain [94]. Under acidic conditions, it interacts and inserts the toxin into the phospholipid bilayer. This facilitates its translocation to the cytosol. In the 2000s, researchers showed that carriers and receptors such as low-density lipoprotein receptor-related protein (LRP), megalin, and clathrin-coated vesicles interact with TCS to form endosomes. Lysosome then helps digest and facilitate the relocation [94-96].

\subsection{Anti-Cancer Properties of TCS}

TCS has potential anti-cancer activities on tumors in the female reproductive system (breast cancer, cervical cancer, and choriocarcinoma), immune system, digestive system (colon cancer, hepatoma, and gastric cancer), blood system, respiratory system, and others [51]. The start of anti-cancer studies of TCS began on gastric and colorectal cancers [3]. In 1993, Wu et al. reported the cytotoxicity of TCS on gastric (MKN-45, SGC-7901, MKN-28) and colorectal cancer (SW-1116, SGC-7402, and ras-positive Wef) cell lines in vitro [97]. In 1995, Zheng et al. showed TCS has selective cytotoxicity on leukemia-lymphoma cells in vitro, which also raised the potential of its treatment on some lymphomas and leukemia [98].

In the SGC-7901-based gastric cancer transplant tumor nude mouse model, TCS also suppressed tumor growth in vivo with an effective suppression dose of $0.5 \mathrm{mg} / \mathrm{kg}$, far lower than the median lethal dose (LD50) $13.4 \mathrm{mg} / \mathrm{kg}$. Combined administration of TCS with fluorouracil (5-FU), mitomycin (MMC), and interferon $\alpha-2 b$ showed higher cytotoxicity on gastric and colorectal cancer cell lines. Takemoto et al. in 1998 reported the anti-tumor activity of the $\mathrm{N}$-terminal sequence of trichosanthin in vivo [99].

The use of TCS to combat cancer is an active research area. Chen et al. showed that TCS inhibits the proliferation, migration, and epithelial-mesenchymal transition of human cervical cancer cells. These were considered mediated by inhibiting the STAT5/C-myc signaling pathway [100]. Smac was shown as another pathway in the anti-cancer activity of TCS in CaSki cervical cancer cells [101]. Zhu et al. showed that regulating oxidative stress-induced apoptosis is one of the TCS mechanisms that inhibit cervical cancer [102]. Tang et al. developed a co-delivery of TCS and Albendazole by the nano-self-assembly system, overcoming multidrug-resistance and metastasis [103]. TCS was found to have the potential to increase the sensitivity of non-small cell lung cancer (NSCLC) TRAILresistance cells [104]. The proposed mechanisms of anti-cancer and TCS-induced apoptosis 
pathways were reviewed by Shi et al. [51]. All these efforts may be favorable for its clinical applications.

\section{Engineering and TCS-Based Immunotoxins}

The engineering and modification studies of RIPs include these aspects: (a) immunotoxins (ITs) made to improve pharmacological performance; (b) engineering of signal sequences to improve specificity; (c) coupling with PEG or dextran to increase the plasma half-life. A pharmacokinetic study of TCS in mice showed that the kidney excreted TCS through urine; the half-life was 8.4-12.7 min. Ko et al. reported coupling with dextran could prolong plasma half-life and minimize renal loss [105]. TCS coupling with PEG5k on Q219C/K173C/S7C showed no significant changes in RIPs activity and cytotoxicity, while the mean residence time and binding affinity of an IgE monoclonal antibody (TE1) to TCS were improved [106]. ITs were also made to improve the specificity of other RIPs. For example, ricin A chain (RTA) and pokeweed antiviral protein (PAP) were linked with HIV envelope glycoprotein and surface antigens for targeting [107-109].

Our group also tried to improve the specificity of RIPs by linking RIPs with HIV1 protease recognition sequences to the C-termini or the internal inactivation region of Maize RIP variants or RTA [110-112]. A switch on a mechanism based on the recognition sequences was proposed to realize higher specificity to the HIV-infected cells instead of normal cells. Subsequently, an in vivo study on Simian immunodeficiency virus (SIV)infected rhesus macaques showed that recombinant active Maize RIP had better-reduced plasma viral burden transiently [112].

Immunotoxins usually consist of a vector part for interaction and a toxin part as the "bullet". The vectors need high affinity, specificity, high stability, and long half-life to the target. Clusters of differentiation (CD) on hematological cells' surfaces are among the most popular used ITs targets. Monoclonal antibodies $(\mathrm{mAb})$ against various cancer antigens, hormones and growth factors, and cytokines were also used [3,107]. The "bullet" of immunotoxins are usually toxins from animals (diphtheria, pseudomonas aeruginosa exotoxin) or plants (ricin, trichosanthin, abrin). The target toxin can be expressed together with the vector or conjugated chemically [113].

In 1987, Wang et al. in China reported using TCS conjugated with monoclonal antibody (mAb) on liver cancer [114]. In 1988, Pierre et al. made immunotoxin based on trichokirin, extracted from T. Kirilowii, and has high homology with TCS [115]. A cleavable dimethyl 3,3'-dithiobispropionimidate cross-linking agent was used to link trichokirin with a monoclonal antibody against Thy 1.2 antigen. The activity of TCS-based ITs was slightly impaired, but the clearance rate was longer compared with ITs of RTA [116]. ITs based on TCS were potent and caused a selective and specific depletion of cholinergic neurons in neostriatum, which performed better than a commercially available immunotoxin containing saporin [117]. These showed that TCS might be a good candidate in immunotoxin development.

In the 1990s, researchers reported the use of ITs of TCS with Hepama-1 (human hepatoma) [89], CMU15A (Lung cancer antigen) [118], anti-p75-anti-mouse IgG (p75: nerve growth factor) [117], Ng76 (Melanoma) [119], and EGF (hepatocellular carcinoma) [120-122] (Table 2). A review on the use of RIPs as immunotoxins is available [76]. 
Table 2. Immunotoxins (ITs) based on TCS.

\begin{tabular}{|c|c|c|c|c|c|}
\hline Time & Immunotoxin & Target Antigen & Disease & Effect & References \\
\hline 1991 & TCS-Hepama-1 & $\begin{array}{l}\text { Hepatoma- } \\
\text { associated } \\
\text { antigen }\end{array}$ & Hepatoma & $\begin{array}{l}\text { Potent and specific antihepatoma agents; } \\
\text { might have considerable potential in } \\
\text { hepatoma therapy. }\end{array}$ & {$[89,123]$} \\
\hline 1992 & $\mathrm{~B}_{3}-\mathrm{IgG}-\mathrm{TCS}$ & $\mathrm{CEA}^{1}$-MAb antigen & $\begin{array}{l}\text { Colorectal cancer; Cervical } \\
\text { cancer }\end{array}$ & Anti-tumor activity in vitro and in vivo & {$[124]$} \\
\hline 1993 & TCS-Hepama-1-gold & $\begin{array}{l}\text { Hepatoma- } \\
\text { associated antigen } \\
\text { and gold }\end{array}$ & Hepatoma & $\begin{array}{l}\text { TCS-Hepama-1-gold particles are bound } \\
\text { to the microvilli of human liver } \\
\text { carcinoma cells and can be inhibited } \\
\text { competitively by pretreatment with } \\
\text { Hepama-1 for an hour. }\end{array}$ & {$[125]$} \\
\hline 1995 & CMU15-TCS & Lung cancer antigen & Lung cancer & $\begin{array}{l}\text { Significant tumor-inhibited effect } \\
\text { in vivo, inhibition rate of tumor growth } \\
\text { reaching } 76 \% \text { in the group of peritoneal } \\
\text { injection and } 99.4 \% \text { in the group of } \\
\text { intra-tumor injection without apparent } \\
\text { toxic effect to host mice }\end{array}$ & {$[118,126]$} \\
\hline 1996 & TCS-Ng76 & Melanoma antigen & Melanoma & $\begin{array}{l}\text { The affinity gel may be used to purify } \\
\text { different TCS-composed immunotoxins. }\end{array}$ & [119] \\
\hline 1997 & H-2 Ag-TCS & $\begin{array}{l}\text { Mouse major } \\
\text { histocompatibility } \\
\text { complex antigens } \\
\text { (H-2 Ag) }\end{array}$ & Rat cardiac xenografts & $\begin{array}{l}\text { The proliferation of recipient immune } \\
\text { cells pretreated with conjugate } \\
\text { H-2Ag-TCS was inhibited. H-2 Ag-TCS } \\
\text { significantly prolonged the cardiac } \\
\text { survival time }\end{array}$ & {$[127]$} \\
\hline 1999 & $\begin{array}{l}\text { p75-TCS (anti-p75 } \\
\text { anti-mouse IgG-TCS) }\end{array}$ & $\begin{array}{l}\text { Rat nerve growth } \\
\text { factor }(\mathrm{NGF)} \text { receptor } \\
\text { (p75 receptor) } \\
\text { (p75NTR) }\end{array}$ & $\begin{array}{c}\text { Immuno-lesioning } \\
\text { (cholinergic basal forebrain } \\
\text { neurons) }\end{array}$ & $\begin{array}{l}\text { Potent and caused a selective and } \\
\text { specific depletion of cholinergic neurons } \\
\text { in the neostriatum }\end{array}$ & [117] \\
\hline 2010 & EGF-TCS & EGFR $^{2}$ & Hepatocellular carcinoma & $\begin{array}{c}\text { Inhibits the growth of solid tumors in } \\
\text { nude mice }\end{array}$ & {$[120]$} \\
\hline 2011 & EGF-TCSredlk & EGFR & Hepatocellular carcinoma & Anti-cancer activity in vivo and in vitro & [121] \\
\hline
\end{tabular}

${ }^{1}$ CEA: carcinoembryonic antigen. ${ }^{2}$ EGFR: Epidermal Growth Factor Receptor.

\section{Conclusion and Perspectives}

Various historic medicines are still sparkling with the modification of advanced technology. Insulin was isolated from the internal secretion of the pancreas by Banting and Macleod in the 1920s [128]. It was then applied to commercialization and bench-to-bedside application for diabetes. Further optimizations of insulin in the following decades were conducted to improve its performance [129]. Recombinant proteins were cloned and used for expression in the 1980s [128,130]. Similar to insulin, TCS is also a natural product. Studies on TCS also formed a history of intelligent collaboration, ceaseless renovation, and bench-to-bedside research.

For the clinical applications of TCS, there are three active areas of work. Before the 1980s, it was abortion. In recent decades, anti-HIV and anti-cancer have become more active. Clinical requirements first motivated the application of TCS as an abortifacient. The ADRs reflected from the clinical application then drove the modification and engineering of TCS. New biological activities inspired novel applications. Its molecular and structural basis as rRNA N-glycosylase (EC 3.2.2.22) supported its engineering for improvement. These made TCS become a showcase of bench-to-bedside translation and drug development from TCM.

As well as clinical applications, TCS has been shown to inhibit plant viruses. Local lesion formation by turnip mosaic virus (TuMV) in leaves of Nicotiana tabacum was inhibited by exogenous application of recombinant TCS. It also caused a delay in the development of mosaic symptoms by TuMV in Brassica parachinensis [131]. The transgenic plant TP3, TP11 with the gene of TCS have shown virus resistance on tobacco mosaic virus (TMV) and cucumber mosaic virus (CMV) [132,133]. 
After TCS, various other RIPs were studied. The distribution of RIPs was also expanded from plants to bacteria [134], animals [135], fungi [136,137], and even mosquitos [138]. A number of these have protein sequences different from the classical RIPs. These new RIPs reveal new mechanisms based on different catalytic centers. An example is lyophyllin from Lyophyllum shimeji. This RIP is a member of the peptidase M35 superfamily but has potent rRNA $N$-glycosylase activity [139].

For pharmaceutical uses, immunogenicity, short plasma half-life, and non-selective cytotoxicity were the major issues to be overcome. Its immunogenicity may cause reduced efficacy through chronic exposure. As well as coupling with polyethylene glycerol and dextran, deimmunization by depleting T-cell epitopes on the protein can be a good way to reduce immunogenicity in designing ITs [140]. Recent studies showed that the clearance of partially unfolded or oxidized proteins by non-target cells such as hepatic Kupffer cells may also affect the cytotoxicity and tolerance of TCS [141-143]. Strategies to improve specificity, such as targeting the protein delivery system [144], show potential to overcome this problem.

There are still many opportunities in the research and development of TCS. New techniques in nanoparticles, co-delivery systems, and tumor-targeting protein delivery systems [103,145] may improve the specificity and reduce the side effects. TCS may be a component of a drug cocktail or combination therapy to increase the efficacy [104,146]. The penetrating peptide (CPP)-fused recombinant TCS toxin conjugated to lactoferrin (LF) has the potential to penetrate the blood-brain barrier (BBB) [146]. A cancer vaccination platform based on TCS was also implemented in 2021 [147], which is a promising tool for cancer immunotherapy. In basic science, studies on the TCS-ribosome complex by Cryo-EM will reveal the detail of interaction.

In conclusion, TCS has emerged from an abortifacient to an anti-HIV and anti-cancer agent. Over the years, modifications have been carried out to improve pharmacological performance, and mechanism studies have been conducted to understand the enzymatic reaction. TCS has become a showcase for the mechanism of function and applied values of this class of proteins. The research and development on TCS have also revealed the hidden treasure in Chinese medicine.

Supplementary Materials: The following supporting information can be downloaded at: https: / / www.mdpi.com/article/10.3390/toxins14030178/s1, Figure S1: Multiple sequence alignment of TCS with other RIPs.

Author Contributions: Conceptualization, P.-C.S.; writing, J.-Q.L.; review and editing: P.-C.S. and K.-B.W. All authors have read and agreed to the published version of the manuscript.

Funding: This research was funded by a General Research Fund from The Research Grants Council of Hong Kong SAR: 14176617.

Institutional Review Board Statement: Not applicable.

Informed Consent Statement: Not applicable.

Data Availability Statement: All data are contained within this article.

Conflicts of Interest: The authors declare no conflict of interest.

\section{References}

1. Shaw, P.C.; Chan, W.L.; Yeung, H.W.; Ng, T.B. Minireview: Trichosanthin-a protein with multiple pharmacological properties. Life Sci. 1994, 55, 253-262. [CrossRef]

2. Chang, M.C.; Saksena, S.K.; Lau, I.F.; Wang, Y.H. Induction of mid-term abortion by trichosanthin in laboratory animals. Contraception 1979, 19, 175-184. [CrossRef]

3. Wang, Y.; Jin, S. Trichosanthin, 2nd ed.; Ke Xue Chu Ban She: Beijing, China, 2000.

4. Tang, S. Chongxiu Zhenghe Jingshi Zhenglei Beiyong Bencao; Hunan Ke Xue Ji Shu Chu Ban She: Changsha, China, 2014.

5. Le, C.; Wei, J.; Lou, Z. Renewed report on study on the identification of Trichosanthin and its similar products. Acta Pharm. Sin. $1982,17,777-782$.

6. Le, C.; Lou, Z. Identification of Trichosanthin and its similar products. Acta Pharm. Sin. 1979, 14, 641-654. 
7. Wang, N.; Xu, G.; Jin, R.; Xu, L. Study on the identification of Trichosanthin. Zhongguo Yao Ke Da Xue Xue Bao 1983, 2, 48-76.

8. Wang, Y. Trichosanthin, 1st ed.; Ke Xue Chu Ban She: Beijing, China, 1990.

9. P., Z. A brief introduction of the use of Trichosanthin. Guang Dong Yi Xue 1974, 10, 16-24.

10. Jin, Y.C. Intra-amniotic injection of crystal trichosanthin for induction of labour in second trimester pregnancy. Sheng $Z h i \mathrm{Yu} B i$ Yun 1985, 5, 15-17, 20.

11. Song, J.F.; Liu, T.; Shen, X.; Wu, G.D.; Xia, Q.C. Application of free-flow electrophoresis to the purification of trichosanthin from a crude product of acetone fractional precipitation. Electrophoresis 1998, 19, 1097-1103. [CrossRef]

12. Jin, S.; Sun, X.; Wang, S.; Tian, G.; Gu, Z.; Qian, W.; Liu, Y.; She, W.; Qian, R.; Wang, Y. Chemistry of Trichosanthin I. physical and chemical properties of crystallized Trichosanthin. Ниа Хие Хие Вао 1981, 39, 513-519.

13. Jin, Y.; Zou, Y. Comparative analysis of intramuscular and cervical injection of crystallized trichosanthin in 200 cases of 10-14 weeks of pregnancy. Sheng Zhi Yu Bi Yun 1990, 10, 34-37.

14. Mondal, A. A novel extraction of trichosanthin from Trichosanthes kirilowii roots using three-phase partitioning and its in vitro anticancer activity. Pharm Biol. 2014, 52, 677-680. [CrossRef] [PubMed]

15. Gu, Z.F.; Wu, X.; Li, Y.; Zhang, P.; Guo, X.; Lv, S. Application of crystallized Trichosanthin prescription to difficult induced abortion-preliminary analyses on 179 patients. Reprod. Contracept. 1985, 1, 10-14.

16. Xu, M.F.; Jin, Y.C. Clinical trial of trichosanthin with or without dexamethasone in induction of abortion by four different routes of administration. Sheng Zhi Yu Bi Yun 1991, 11, 47-50.

17. Katzin, L. Compound Q clinical tests begin. Am. J. Nurs. 1989, 89, 916. [CrossRef] [PubMed]

18. Kahn, J.O.; Kaplan, L.D.; Gambertoglio, J.G.; Bredesen, D.; Arri, C.J.; Turin, L.; Kibort, T.; Williams, R.L.; Lifson, J.D.; Volberding, P.A. The safety and pharmacokinetics of GLQ223 in subjects with AIDS and AIDS-related complex: A phase I study. AIDS 1990, 4, 1197-1204. [CrossRef] [PubMed]

19. Byers, V.S.; Levin, A.S.; Waites, L.A.; Starrett, B.A.; Mayer, R.A.; Clegg, J.A.; Price, M.R.; Robins, R.A.; Delaney, M.; Baldwin, R.W A phase I/II study of trichosanthin treatment of HIV disease. AIDS 1990, 4, 1189-1196. [CrossRef]

20. Gatti, G.; Kahn, J.O.; Lifson, J.; Williams, R.; Turin, L.; Volberding, P.A.; Gambertoglio, J.G. Pharmacokinetics of GLQ223 in rats, monkeys, and patients with AIDS or AIDS-related complex. Antimicrob. Agents Chemother. 1991, 35, 2531-2537. [CrossRef]

21. Zhou, G.; Zheng, Z.; Lu, D. Safety, efficacy and mechanism of trichosanthin therapy for AIDS. Shang Hai Mian Yi Xue Za Zhi 1992, 12, 116-120.

22. Garcia, P.A.; Bredesen, D.E.; Vinters, H.V.; Graefin von Einsiedel, R.; Williams, R.L.; Kahn, J.O.; Byers, V.S.; Levin, A.S.; Waites, L.A.; Messing, R.O. Neurological reactions in HIV-infected patients treated with trichosanthin. Neuropathol. Appl. Neurobiol. 1993, 19, 402-405. [CrossRef]

23. Kahn, J.O.; Gorelick, K.J.; Gatti, G.; Arri, C.J.; Lifson, J.D.; Gambertoglio, J.G.; Bostrom, A.; Williams, R. Safety, activity, and pharmacokinetics of GLQ223 in patients with AIDS and AIDS-related complex. Antimicrob. Agents Chemother. 1994, 38, $260-267$. [CrossRef]

24. Huang, J.; Jin, Y. Analysis of Trichosanthin Cervix injection to induce abortion and dexamethasone to reduce side effects. Xian Dai Fu Chan Ke Jin Zhan 1994, 3, 227-228.

25. Zhang, S.; Jin, Y.; Yu, J.; Qi, W.; Liu, Y.; Xue, M.; Chen, M. Further study on the effect of trichosanthin induced Abortion on heart, liver and kidney function in pregnant women. Sheng Zhi Yu Bi Yun 1994, 14, 19-24.

26. Byers, V.S.; Levin, A.S.; Malvino, A.; Waites, L.; Robins, R.A.; Baldwin, R.W. A phase II study of effect of addition of trichosanthin to zidovudine in patients with HIV disease and failing antiretroviral agents. AIDS Res. Hum. Retrovir. 1994, 10, 413-420. [CrossRef] [PubMed]

27. Chun, L.; Yucui, J. Clinical observation of the effect intracervical and intramuscular injection of Trichosanthin on tubal pregnancy. J. Shanghai Jiaotong Univ. (Med. Sci) 2000, 20, 447-449.

28. Wang, J.; Jin, Y. Comparative study in three methods of medicinal abortion of mid-term pregenancy. Shang Hai Di Er Jun Yi Da Хие Хие Вао 2001, 21, 264-266.

29. Leung, K.N.; Yeung, H.W.; Leung, S.O. The immunomodulatory and antitumor activities of trichosanthin-an abortifacient protein isolated from tian-hua-fen (Trichosanthes kirilowii). Asian Pac. J. Allergy Immunol. 1986, 4, 111-120.

30. Chan, W.Y.; Ng, T.B.; Yeung, H.W. Trichosanthin as an abortifacient for terminating early pregnancy in mice. Int. J. Fertil. 1993, 38 , 99-107.

31. Chu, J.J.; Devall, A.J.; Beeson, L.E.; Hardy, P.; Cheed, V.; Sun, Y.; Roberts, T.E.; Ogwulu, C.O.; Williams, E.; Jones, L.L.; et al. Mifepristone and misoprostol versus misoprostol alone for the management of missed miscarriage (MifeMiso): A randomised, double-blind, placebo-controlled trial. Lancet 2020, 396, 770-778. [CrossRef]

32. Wang, Y.; Qian, R.-Q.; Gu, Z.-W.; Jin, S.-W.; Zhang, L.-Q.; Xia, Z.-X.; Tian, G.-Y.; Ni, C.-Z. Scientific evaluation of Tian Hua Fen (THF)-history, chemistry and application. Pure Appl. Chem. 1986, 58, 789-798. [CrossRef]

33. Collins, E.J.; Robertus, J.D.; LoPresti, M.; Stone, K.L.; Williams, K.R.; Wu, P.; Hwang, K.; Piatak, M. Primary amino acid sequence of alpha-trichosanthin and molecular models for abrin A-chain and alpha-trichosanthin. J. BioL. Chem. 1990, 265, 8665-8669. [CrossRef]

34. Wang, Y.; Gu, Z.; Ye, G.; Sun, X.; Wang, Q.; Jin, S. Revision of the primary structure of trichosanthin and study on the trichosanthin from different places of origin. Acta Chim. Sin. 1993, 51, 1023-1029. 
35. Chow, T.P.; Feldman, R.A.; Lovett, M.; Piatak, M. Isolation and DNA sequence of a gene encoding alpha-trichosanthin, a type I ribosome-inactivating protein. J Biol Chem 1990, 265, 8670-8674. [CrossRef]

36. Shaw, P.C.; Yung, M.H.; Zhu, R.H.; Ho, W.K.; Ng, T.B.; Yeung, H.W. Cloning of trichosanthin cDNA and its expression in Escherichia coli. Gene 1991, 97, 267-272. [CrossRef]

37. Zhu, R.H.; Ng, T.B.; Yeung, H.W.; Shaw, P.C. High level synthesis of biologically active recombinant trichosanthin in Escherichia coli. Int. J. Pept. Protein Res. 1992, 39, 77-81. [CrossRef]

38. Zhang, J.S.; Liu, W.Y. The mechanism of action of trichosanthin on eukaryotic ribosomes-RNA N-glycosidase activity of the cytotoxin. Nucleic Acids Res. 1992, 20, 1271-1275. [CrossRef] [PubMed]

39. Endo, Y.; Mitsui, K.; Motizuki, M.; Tsurugi, K. The mechanism of action of ricin and related toxic lectins on eukaryotic ribosomes. The site and the characteristics of the modification in $28 \mathrm{~S}$ ribosomal RNA caused by the toxins. J. Biol. Chem. 1987, 262, 5908-5912. [CrossRef]

40. Endo, Y.; Chan, Y.L.; Lin, A.; Tsurugi, K.; Wool, I.G. The cytotoxins alpha-sarcin and ricin retain their specificity when tested on a synthetic oligoribonucleotide (35-mer) that mimics a region of $28 \mathrm{~S}$ ribosomal ribonucleic acid. J. Biol. Chem. 1988, 263, 7917-7920. [CrossRef]

41. Nilsson, L.; Nygard, O. The mechanism of the protein-synthesis elongation cycle in eukaryotes. Effect of ricin on the ribosomal interaction with elongation factors. Eur. J. Biochem. 1986, 161, 111-117. [CrossRef]

42. Choi, A.K.; Wong, E.C.; Lee, K.M.; Wong, K.B. Structures of eukaryotic ribosomal stalk proteins and its complex with trichosanthin, and their implications in recruiting ribosome-inactivating proteins to the ribosomes. Toxins 2015, 7, 638-647. [CrossRef]

43. Grela, P.; Szajwaj, M.; Horbowicz-Drożdżal, P.; Tchórzewski, M. How ricin damages the ribosome. Toxins 2019, 11, 241. [CrossRef]

44. Voorhees, R.M.; Schmeing, T.M.; Kelley, A.C.; Ramakrishnan, V. The mechanism for activation of GTP hydrolysis on the ribosome. Science 2010, 330, 835-838. [CrossRef] [PubMed]

45. Wu, S.; Lu, X.; Zhu, Y.; Yang, J.; Dong, Y. N-glycosidase mechanism of Trichosanthin. Sci. China C Life Sci. 1998, 41, 174-180. [CrossRef]

46. Huang, Q.; Liu, S.; Tang, Y.; Jin, S.; Wang, Y. Studies on crystal structures, active-centre geometry and depurinating mechanism of two ribosome-inactivating proteins. Biochem. J. 1995, 309, 285-298. [CrossRef] [PubMed]

47. Ren, J.; Wang, Y.; Dong, Y.; Stuart, D.I. The N-glycosidase mechanism of ribosome-inactivating proteins implied by crystal structures of alpha-momorcharin. Structure 1994, 2, 7-16. [CrossRef]

48. Monzingo, A.F.; Robertus, J.D. X-ray analysis of substrate analogs in the ricin A-chain active site. J. Mol. Biol. 1992, 227, 1136-1145. [CrossRef]

49. Xiong, J.P.; Xia, Z.X.; Wang, Y. Identification of a stable complex of trichosanthin with nicotinamide adenine dinucleotide phosphate. J. Protein Chem. 1995, 14, 139-144. [CrossRef]

50. Xiong, J.P.; Xia, Z.X.; Wang, Y. Crystal structure of trichosanthin-NADPH complex at 1.7 A resolution reveals active-site architecture. Nat. Struct. Biol. 1994, 1, 695-700. [CrossRef]

51. Shi, W.W.; Wong, K.B.; Shaw, P.C. Structural and functional investigation and pharmacological mechanism of Trichosanthin, a type 1 ribosome-inactivating protein. Toxins 2018, 10, 335. [CrossRef]

52. Frankel, A.; Welsh, P.; Richardson, J.; Robertus, J.D. Role of arginine 180 and glutamic acid 177 of ricin toxin A chain in enzymatic inactivation of ribosomes. Mol. Cell Biol. 1990, 10, 6257-6263. [CrossRef]

53. Ready, M.P.; Kim, Y.; Robertus, J.D. Site-directed mutagenesis of ricin A-chain and implications for the mechanism of action. Proteins 1991, 10, 270-278. [CrossRef]

54. Wong, K.B.; Ke, Y.B.; Dong, Y.C.; Li, X.B.; Guo, Y.W.; Yeung, H.W.; Shaw, P.C. Structure/function relationship study of Gln156, Glu160 and Glu189 in the active site of trichosanthin. Eur. J. Biochem. 1994, 221, 787-791. [CrossRef] [PubMed]

55. Gu, Y.J.; Xia, Z.X. Crystal structures of the complexes of trichosanthin with four substrate analogs and catalytic mechanism of RNA N-glycosidase. Proteins 2000, 39, 37-46. [CrossRef]

56. Shi, W.W.; Mak, A.N.; Wong, K.B.; Shaw, P.C. Structures and ribosomal interaction of ribosome-inactivating proteins. Molecules 2016, 21, 1588. [CrossRef] [PubMed]

57. Chan, S.H.; Hung, F.S.; Chan, D.S.; Shaw, P.C. Trichosanthin interacts with acidic ribosomal proteins P0 and P1 and mitotic checkpoint protein MAD2B. Eur. J. Biochem. 2001, 268, 2107-2112. [CrossRef]

58. Tchorzewski, M. The acidic ribosomal P proteins. Int. J. Biochem. Cell Biol. 2002, 34, 911-915. [CrossRef]

59. Ban, N.; Beckmann, R.; Cate, J.H.; Dinman, J.D.; Dragon, F.; Ellis, S.R.; Lafontaine, D.L.; Lindahl, L.; Liljas, A.; Lipton, J.M.; et al. A new system for naming ribosomal proteins. Curr. Opin. Struct. Biol. 2014, 24, 165-169. [CrossRef]

60. Grela, P.; Gajda, M.J.; Armache, J.P.; Beckmann, R.; Krokowski, D.; Svergun, D.I.; Grankowski, N.; Tchórzewski, M. Solution structure of the natively assembled yeast ribosomal stalk determined by small-angle X-ray scattering. Biochem. J. 2012, 444, 205-209. [CrossRef]

61. Chan, D.S.; Chu, L.O.; Lee, K.M.; Too, P.H.; Ma, K.W.; Sze, K.H.; Zhu, G.; Shaw, P.C.; Wong, K.B. Interaction between trichosanthin, a ribosome-inactivating protein, and the ribosomal stalk protein $\mathrm{P} 2$ by chemical shift perturbation and mutagenesis analyses. Nucleic Acids Res. 2007, 35, 1660-1672. [CrossRef]

62. Szajwaj, M.; Wawiórka, L.; Molestak, E.; Michalec-Wawiórka, B.; Mołoń, M.; Wojda, I.; Tchórzewski, M. The influence of ricinmediated rRNA depurination on the translational machinery in vivo-New insight into ricin toxicity. Biochim. Biophys. Acta Mol. Cell Res. 2019, 1866, 118554. [CrossRef] 
63. Too, P.H.; Ma, M.K.; Mak, A.N.; Wong, Y.T.; Tung, C.K.; Zhu, G.; Au, S.W.; Wong, K.B.; Shaw, P.C. The C-terminal fragment of the ribosomal $\mathrm{P}$ protein complexed to trichosanthin reveals the interaction between the ribosome-inactivating protein and the ribosome. Nucleic Acids Res. 2009, 37, 602-610. [CrossRef]

64. Lee, K.M.; Yusa, K.; Chu, L.O.; Yu, C.W.; Oono, M.; Miyoshi, T.; Ito, K.; Shaw, P.C.; Wong, K.B.; Uchiumi, T. Solution structure of human $\mathrm{P} 1{ }^{*} \mathrm{P} 2$ heterodimer provides insights into the role of eukaryotic stalk in recruiting the ribosome-inactivating protein trichosanthin to the ribosome. Nucleic Acids Res. 2013, 41, 8776-8787. [CrossRef] [PubMed]

65. Lee, K.M.; Yu, C.W.; Chan, D.S.; Chiu, T.Y.; Zhu, G.; Sze, K.H.; Shaw, P.C.; Wong, K.B. Solution structure of the dimerization domain of ribosomal protein P2 provides insights for the structural organization of eukaryotic stalk. Nucleic Acids Res. 2010, 38, 5206-5216. [CrossRef]

66. Lee, K.M.; Yu, C.W.; Chiu, T.Y.; Sze, K.H.; Shaw, P.C.; Wong, K.B. Solution structure of the dimerization domain of the eukaryotic stalk P1/P2 complex reveals the structural organization of eukaryotic stalk complex. Nucleic Acids Res. 2012, 40, 3172-3182. [CrossRef] [PubMed]

67. Wawiórka, L.; Molestak, E.; Szajwaj, M.; Michalec-Wawiórka, B.; Mołoń, M.; Borkiewicz, L.; Grela, P.; Boguszewska, A.; Tchórzewski, M. Multiplication of ribosomal P-stalk proteins contributes to the fidelity of translation. Mol. Cell Biol. 2017, 37, e00060-17. [CrossRef] [PubMed]

68. Li, X.P.; Grela, P.; Krokowski, D.; Tchórzewski, M.; Tumer, N.E. Pentameric organization of the ribosomal stalk accelerates recruitment of ricin a chain to the ribosome for depurination. J. Biol. Chem. 2010, 285, 41463-41471. [CrossRef]

69. Grela, P.; Li, X.P.; Horbowicz, P.; Dźwierzyńska, M.; Tchórzewski, M.; Tumer, N.E. Human ribosomal P1-P2 heterodimer represents an optimal docking site for ricin A chain with a prominent role for P1 C-terminus. Sci. Rep. 2017, 7, 5608. [CrossRef]

70. Horbowicz-Drozdzal, P.; Kamel, K.; Kmiecik, S.; Borkiewicz, L.; Tumer, N.E.; Shaw, P.C.; Tchorzewski, M.; Grela, P. Phosphorylation of the conserved C-terminal domain of ribosomal P-proteins impairs the mode of interaction with plant toxins. FEBS Lett. 2021, 595, 2221-2236. [CrossRef]

71. Shi, W.W.; Tang, Y.S.; Sze, S.Y.; Zhu, Z.N.; Wong, K.B.; Shaw, P.C. Crystal structure of ribosome-inactivating protein ricin A chain in complex with the C-terminal peptide of the ribosomal stalk protein P2. Toxins 2016, 8, 296. [CrossRef]

72. McGrath, M.S.; Santulli, S.; Gaston, I. Effects of GLQ223 on HIV replication in human monocyte/macrophages chronically infected in vitro with HIV. AIDS Res. Hum. Retrovir. 1990, 6, 1039-1043. [CrossRef]

73. McGrath, M.S.; Hwang, K.M.; Caldwell, S.E.; Gaston, I.; Luk, K.C.; Wu, P.; Ng, V.L.; Crowe, S.; Daniels, J.; Marsh, J.; et al GLQ223: An inhibitor of human immunodeficiency virus replication in acutely and chronically infected cells of lymphocyte and mononuclear phagocyte lineage. Proc. Natl. Acad. Sci. USA 1989, 86, 2844-2848. [CrossRef]

74. Ferrari, P.; Trabaud, M.A.; Rommain, M.; Mandine, E.; Zalisz, R.; Desgranges, C.; Smets, P. Toxicity and activity of purified trichosanthin. AIDS 1991, 5, 865-870. [CrossRef] [PubMed]

75. Fang, E.F.; Ng, T.B.; Shaw, P.C.; Wong, R.N. Recent progress in medicinal investigations on trichosanthin and other ribosome inactivating proteins from the plant genus Trichosanthes. Curr. Med. Chem. 2011, 18, 4410-4417. [CrossRef] [PubMed]

76. Lu, J.Q.; Zhu, Z.N.; Zheng, Y.T.; Shaw, P.C. Engineering of ribosome-inactivating proteins for improving pharmacological properties. Toxins 2020, 12, 167. [CrossRef] [PubMed]

77. Zhao, W.L.; Feng, D.; Wu, J.; Sui, S.F. Trichosanthin inhibits integration of human immunodeficiency virus type 1 through depurinating the long-terminal repeats. Mol. Biol. Rep. 2010, 37, 2093-2098. [CrossRef] [PubMed]

78. Zhao, W.L.; Zhang, F.; Feng, D.; Wu, J.; Chen, S.; Sui, S.F. A novel sorting strategy of trichosanthin for hijacking human immunodeficiency virus type 1. Biochem. Biophys. Res. Commun. 2009, 384, 347-351. [CrossRef]

79. Li, M.X.; Yeung, H.W.; Pan, L.P.; Chan, S.I. Trichosanthin, a potent HIV-1 inhibitor, can cleave supercoiled DNA in vitro. Nucleic Acids Res. 1991, 19, 6309-6312. [CrossRef]

80. Wang, J.H.; Nie, H.L.; Huang, H.; Tam, S.C.; Zheng, Y.T. Independency of anti-HIV-1 activity from ribosome-inactivating activity of trichosanthin. Biochem. Biophys/Res. Commun. 2003, 302, 89-94. [CrossRef]

81. Huang, H.; Chan, H.; Wang, Y.Y.; Ouyang, D.Y.; Zheng, Y.T.; Tam, S.C. Trichosanthin suppresses the elevation of p38 MAPK, and Bcl-2 induced by HSV-1 infection in Vero cells. Life Sci. 2006, 79, 1287-1292. [CrossRef]

82. Bodmer, D.; Gloddek, B.; Ryan, A.F.; Huverstuhl, J.; Brors, D. Inhibition of the c-Jun N-terminal kinase signaling pathway influences neurite outgrowth of spiral ganglion neurons in vitro. Laryngoscope 2002, 112, 2057-2061. [CrossRef]

83. Pinching, A.J. Early trials of GLQ223/trichosanthin: What do they show? AIDS 1990, 4, 1289-1291. [CrossRef]

84. Kolata, G. Trial of experimental AIDS drug to be continued, with revisions. N Y Times Web 1990, A1, A15.

85. McGrath, M.S.; Lifson, J.D. Compound Q. Nature 1990, 343, 304. [CrossRef] [PubMed]

86. Palca, J. Trials and tribulations of AIDS drug testing. Science 1990, 247, 1406. [CrossRef] [PubMed]

87. Byers, V.S.; Baldwin, P.W. Trichosanthin treatment of HIV disease. AIDS 1991, 5, 1150-1151. [PubMed]

88. An, Q.; Lei, Y.; Jia, N.; Zhang, X.; Bai, Y.; Yi, J.; Chen, R.; Xia, A.; Yang, J.; Wei, S.; et al. Effect of site-directed PEGylation of trichosanthin on its biological activity, immunogenicity, and pharmacokinetics. Biomol. Eng. 2007, 24, 643-649. [CrossRef]

89. Wang, Q.C.; Ying, W.B.; Xie, H.; Zhang, Z.C.; Yang, Z.H.; Ling, L.Q. Trichosanthin-monoclonal antibody conjugate specifically cytotoxic to human hepatoma cells in vitro. Cancer. Res. 1991, 51, 3353-3355. [PubMed]

90. Lu, D.Y.; Wu, H.Y.; Yarla, N.S.; Xu, B.; Ding, J.; Lu, T.R. HAART in HIV/AIDS Treatments: Future Trends. Infect. Disord. Drug Targets 2018, 18, 15-22. [CrossRef] 
91. Chan, W.L.; Zheng, Y.T.; Huang, H.; Tam, S.C. Relationship between trichosanthin cytotoxicity and its intracellular concentration. Toxicology 2002, 177, 245-251. [CrossRef]

92. Sandvig, K.; Olsnes, S.; Pihl, A. Kinetics of binding of the toxic lectins abrin and ricin to surface receptors of human cells. J. Biol. Chem. 1976, 251, 3977-3984. [CrossRef]

93. Spooner, R.A.; Lord, J.M. Ricin trafficking in cells. Toxins 2015, 7, 49-65. [CrossRef]

94. Xia, X.F.; Zhang, F.; Shaw, P.C.; Sui, S.F. Trichosanthin induces leakage and membrane fusion of liposome. IUBMB Life 2003, 55, 681-687. [CrossRef] [PubMed]

95. Chan, W.Y.; Huang, H.; Tam, S.C. Receptor-mediated endocytosis of trichosanthin in choriocarcinoma cells. Toxicology 2003, 186, 191-203. [CrossRef]

96. Chan, W.L.; Shaw, P.C.; Tam, S.C.; Jacobsen, C.; Gliemann, J.; Nielsen, M.S. Trichosanthin interacts with and enters cells via LDL receptor family members. Biochem. Biophys. Res. Commun. 2000, 270, 453-457. [CrossRef] [PubMed]

97. Wu, Y.; Xiang, D.; Zhang, Y.; Jiang, S.; Tu, S.; Qiao, M.; Shen, B. Cytotoxicity of trichosanthin to gastric and colonic cancer cells in vitro. Chin. J. Dig. 1993, 13, 263-266.

98. Zheng, Y.T.; Zhang, W.F.; Ben, K.L.; Wang, J.H. In vitro immunotoxicity and cytotoxicity of trichosanthin against human normal immunocytes and leukemia-lymphoma cells. Immunopharmacol. Immunotoxicol. 1995, 17, 69-79. [CrossRef] [PubMed]

99. Takemoto, D.J. Effect of trichosanthin an anti-leukemia protein on normal mouse spleen cells. Anticancer. Res. 1998, 18, 357-361.

100. Chen, Y.; Han, L.; Bai, L.; Tang, H.; Zheng, A. Trichosanthin inhibits the proliferation of cervical cancer cells and downregulates STAT-5/C-myc signaling pathway. Pathol. Res. Pract. 2019, 215, 632-638. [CrossRef]

101. Cui, L.; Song, J.; Wu, L.; Huang, L.; Wang, Y.; Huang, Y.; Yu, H.; Huang, Y.; You, C.C.; Ye, J. Smac is another pathway in the anti-tumour activity of Trichosanthin and reverses Trichosanthin resistance in CaSki cervical cancer cells. Biomed. Pharm. 2015, 69, 119-124. [CrossRef]

102. Zhu, C.; Zhang, C.; Cui, X.; Wu, J.; Cui, Z.; Shen, X. Trichosanthin inhibits cervical cancer by regulating oxidative stress-induced apoptosis. Bioengineered 2021, 12, 2779-2790. [CrossRef]

103. Tang, Y.; Liang, J.; Wu, A.; Chen, Y.; Zhao, P.; Lin, T.; Zhang, M.; Xu, Q.; Wang, J.; Huang, Y. Co-delivery of Trichosanthin and Albendazole by nano-self-assembly for overcoming tumor multidrug-resistance and metastasis. ACS Appl. Mater. Interfaces 2017, 9, 26648-26664. [CrossRef]

104. You, C.; Sun, Y.; Zhang, S.; Tang, G.; Zhang, N.; Li, C.; Tian, X.; Ma, S.; Luo, Y.; Sun, W.; et al. Trichosanthin enhances sensitivity of non-small cell lung cancer (NSCLC) TRAIL-resistance cells. Int. J. Biol. Sci. 2018, 14, 217-227. [CrossRef] [PubMed]

105. Ko, W.H.; Wong, C.C.; Yeung, H.W.; Yung, M.H.; Shaw, P.C.; Tam, S.C. Increasing the plasma half-life of trichosanthin by coupling to dextran. Biochem. Pharmacol. 1991, 42, 1721-1728. [CrossRef]

106. He, X.H.; Shaw, P.C.; Xu, L.H.; Tam, S.C. Site-directed polyethylene glycol modification of trichosanthin: Effects on its biological activities, pharmacokinetics, and antigenicity. Life Sci. 1999, 64, 1163-1175. [CrossRef]

107. Gilabert-Oriol, R.; Weng, A.; Mallinckrodt, B.; Melzig, M.F.; Fuchs, H.; Thakur, M. Immunotoxins constructed with ribosomeinactivating proteins and their enhancers: A lethal cocktail with tumor specific efficacy. Curr. Pharm. Des. 2014, 20, 6584-6643. [CrossRef] [PubMed]

108. Pincus, S.H.; Fang, H.; Wilkinson, R.A.; Marcotte, T.K.; Robinson, J.E.; Olson, W.C. In vivo efficacy of anti-glycoprotein 41, but not anti-glycoprotein 120, immunotoxins in a mouse model of HIV infection. J. Immunol. 2003, 170, 2236-2241. [CrossRef]

109. Matsushita, S.; Koito, A.; Maeda, Y.; Hattori, T.; Takatsuki, K. Selective killing of HIV-infected cells by anti-gp120 immunotoxins. AIDS Res Hum Retrovir. 1990, 6, 193-203. [CrossRef]

110. Law, S.K.; Wang, R.R.; Mak, A.N.; Wong, K.B.; Zheng, Y.T.; Shaw, P.C. A switch-on mechanism to activate maize ribosomeinactivating protein for targeting HIV-infected cells. Nucleic Acids Res. 2010, 38, 6803-6812. [CrossRef]

111. Au, K.Y.; Wang, R.R.; Wong, Y.T.; Wong, K.B.; Zheng, Y.T.; Shaw, P.C. Engineering a switch-on peptide to ricin A chain for increasing its specificity towards HIV-infected cells. Biochim. Biophys. Acta. 2014, 1840, 958-963. [CrossRef]

112. Wang, R.R.; Au, K.Y.; Zheng, H.Y.; Gao, L.M.; Zhang, X.; Luo, R.H.; Law, S.K.; Mak, A.N.; Wong, K.B.; Zhang, M.X.; et al. The recombinant maize ribosome-inactivating protein transiently reduces viral load in SHIV89.6 infected Chinese Rhesus Macaques. Toxins 2015, 7, 156-169. [CrossRef]

113. Kreitman, R.J. Immunotoxins for targeted cancer therapy. AAPS J. 2006, 8, E532-E551. [CrossRef]

114. Wang, Q.; Zhang, Z.; Wang, J.; Xie, H.; Yang, Z. Trichosanthin has potent inhibiting activity of protein synthesis in a cell-free system and its antibody-conjugate exhibits potentiated cytotoxicity to tumor cells in vitro. Shi Yan Sheng Wu Xue Bao 1987, 20, 515-519. [PubMed]

115. Casellas, P.; Dussossoy, D.; Falasca, A.I.; Barbieri, L.; Guillemot, J.C.; Ferrara, P.; Bolognesi, A.; Cenini, P.; Stirpe, F. Trichokirin, a ribosome-inactivating protein from the seeds of Trichosanthes kirilowii Maximowicz. Purification, partial characterization and use for preparation of immunotoxins. Eur. J. Biochem. 1988, 176, 581-588. [CrossRef] [PubMed]

116. Bourrie, B.J.; Casellas, P.; Blythman, H.E.; Jansen, F.K. Study of the plasma clearance of antibody-ricin-A-chain immunotoxins. Evidence for specific recognition sites on the A chain that mediate rapid clearance of the immunotoxin. Eur. J. Biochem. 1986, 155, 1-10. [CrossRef] [PubMed]

117. Kwok, K.H.; Law, K.B.; Wong, R.N.; Yung, K.K. Immunolesioning of nerve growth factor p75 receptor-containing neurons in the rat brain by a novel immunotoxin: Anti-p75-anti-mouse IgG-trichosanthin conjugates. Brain Res. 1999, 846, 154-163. [CrossRef] 
118. Lu, J.; Liu, X.; Wang, M. The Preparation of McAB TCS Conjugate and Its in VItro Tests of Cytotoxicity Against Human Lung Cancer Cell. J. China Med. Univ. 1994, 4, 335-338.

119. Yuan, H.; Ji, R.; Zhang, R.; Cao, H.; Zhang, Z. Purification of trichosanthin-monoclonal antibody conjugate by monoclonal antibody affinity chromatography. Zhongguo Mian Yi Xue Za Zhi 1996, 12, 246-249.

120. Li, Y.; Chen, J.; Yang, H.; Luo, R. Purification of EGF-TCS recombinant fusion protein and its targeting action on human tumor cells in vitro. J. Third Mil. Med. Univ. 2007, 13, 1316-1319.

121. Li, Y.; Huo, Y.; Yang, M. Antitumor Effect of Recombinant Immunotoxin EGF-TCSredlk on Tumor-bearing Mouse Model. J. Chang. Univ. Tradit. Chin. Med. 2011, 5, 9.

122. Yang, H.W.; Yang, H.W.; Li, Y.M. Antitumor effect of recombinant immunotoxin EGF-TCS in nude mice bearing human hepatocellular carcinoma. Nan Fang Yi Ke Da Xue Xue Bao 2007, 27, 1535-1536.

123. Wen-Jie, L.Q.J.Y.-C.L. Antitumor effect of TCS-hepama-1 immunotoxin and its combined use with ADM on human hepatoma bearing nude mice. Chin. J. Clin. Oncol. 1997, 24, 4-8.

124. Gao, H.L.; Zhou, G.Y.; Lu, D.Y.; Zhang, W.Y. Trichosanthin-CEA MAb conjugate cytotoxic to human colonic carcinoma. Chin. J. Immunol. 1992, 8, 300.

125. Dai, R.X.; Xu, G.J.; Lin, X.Y.; Liu, L.Y.; Shen, H.P.; Zhou, X.G.; Gao, T.; Wang, Y.H. Studies on injury-mechanism of trichosanthin on trophoblast cells and choriocarcinoma cells in culture. Shi Yan Sheng Wu Xue Bao 1993, 26, 411-427. [PubMed]

126. Lu, J.; Li, Y.; Liu, X. Targeting treatment with immunotoxin Trichosanthin conjugated with monoclonal antibody on nude mice model bearing humen lung adenocarcinoma. China Med. Univ. 1995, 3, 243-246.

127. Lan, P.; Zhan, W.; Wang, J. Effect of donor antigen-TCS on survival time of mouse to rat cardiac xenografts. Zhonghua Yi Xue Za Zhi 1997, 77, 847-849. [PubMed]

128. Hegele, R.A.; Maltman, G.M. Insulin's centenary: The birth of an idea. Lancet Diabetes Endocrinol. 2020, 8, 971-977. [CrossRef]

129. Roth, J.; Qureshi, S.; Whitford, I.; Vranic, M.; Kahn, C.R.; Fantus, I.G.; Dirks, J.H. Insulin's discovery: New insights on its ninetieth birthday. Diabetes Metab. Res. Rev. 2012, 28, 293-304. [CrossRef]

130. Lee, S.H.; Yoon, K.H. A century of progress in diabetes care with Insulin: A history of innovations and foundation for the future. Diabetes Metab J. 2021, 45, 629-640. [CrossRef]

131. Lam, Y.; Wong, Y.; Wang, B.; Wong, R.; Yeung, H.; Shaw, P.C. Use of trichosanthin to reduce infection by turnip mosaic virus. Plant Sci. 1996, 114, 111-117. [CrossRef]

132. Jiang, G.Y.; Jin, D.M.; Weng, M.L.; Guo, B.T.; Wang, B. Transformation and expression of trichosanthin gene in tomato. J. Integr. Plant Biol. 1999, 41, 334-336.

133. Krishnan, R.; McDonald, K.A.; Dandekar, A.M.; Jackman, A.P.; Falk, B. Expression of recombinant trichosanthin, a ribosomeinactivating protein, in transgenic tobacco. J. Biotechnol. 2002, 97, 69-88. [CrossRef]

134. Huang, A.; Friesen, J.; Brunton, J.L. Characterization of a bacteriophage that carries the genes for production of Shiga-like toxin 1 in Escherichia coli. J. Bacteriol. 1987, 169, 4308-4312. [CrossRef] [PubMed]

135. Barbieri, L.; Valbonesi, P.; Bondioli, M.; Alvarez, M.L.; Dal Monte, P.; Landini, M.P.; Stirpe, F. Adenine glycosylase activity in mammalian tissues: An equivalent of ribosome-inactivating proteins. FEBS Lett. 2001, 505, 196-197. [CrossRef]

136. Lam, S.K.; Ng, T.B. First simultaneous isolation of a ribosome inactivating protein and an antifungal protein from a mushroom (Lyophyllum shimeji) together with evidence for synergism of their antifungal effects. Arch. Biochem. Biophys. 2001, 393, 271-280. [CrossRef] [PubMed]

137. Yao, Q.Z.; Yu, M.M.; Ooi, L.S.; Ng, T.B.; Chang, S.T.; Sun, S.S.; Ooi, V.E. Isolation and Characterization of a Type 1 RibosomeInactivating Protein from Fruiting Bodies of the Edible Mushroom (Volvariella volvacea). J. Agric. Food Chem. 1998, 46, 788-792. [CrossRef] [PubMed]

138. Wong, J.H.; Bao, H.; Ng, T.B.; Chan, H.H.L.; Ng, C.C.W.; Man, G.C.W.; Wang, H.; Guan, S.; Zhao, S.; Fang, E.F.; et al. New ribosome-inactivating proteins and other proteins with protein synthesis-inhibiting activities. Appl. Microbiol. Biotechnol. 2020, 104, 4211-4226. [CrossRef]

139. Lu, J.Q.; Shi, W.W.; Xiao, M.J.; Tang, Y.S.; Zheng, Y.T.; Shaw, P.C. Lyophyllin, a mushroom protein from the peptidase M35 superfamily is an RNA N-glycosidase. Int. J. Mol. Sci. 2021, 22, 11598. [CrossRef]

140. Baker, M.P.; Reynolds, H.M.; Lumicisi, B.; Bryson, C.J. Immunogenicity of protein therapeutics: The key causes, consequences and challenges. Self Nonself 2010, 1, 314-322. [CrossRef]

141. Kumar, V.; Xin, X.; Ma, J.; Tan, C.; Osna, N.; Mahato, R.I. Therapeutic targets, novel drugs, and delivery systems for diabetes associated NAFLD and liver fibrosis. Adv. Drug Deliv. Rev. 2021, 176, 113888. [CrossRef]

142. Meyer, D.W.; Bou, L.B.; Shum, S.; Jonas, M.; Anderson, M.E.; Hamilton, J.Z.; Hunter, J.H.; Wo, S.W.; Wong, A.O.; Okeley, N.M. An in vitro assay using cultured kupffer cells can predict the impact of drug conjugation on in vivo antibody pharmacokinetics. Mol. Pharm. 2020, 17, 802-809. [CrossRef]

143. Breous, E.; Somanathan, S.; Vandenberghe, L.H.; Wilson, J.M. Hepatic regulatory T cells and Kupffer cells are crucial mediators of systemic $\mathrm{T}$ cell tolerance to antigens targeting murine liver. Hepatology 2009, 50, 612-621. [CrossRef]

144. Chen, Y.; Zhang, M.; Jin, H.; Li, D.; Xu, F.; Wu, A.; Wang, J.; Huang, Y. Glioma Dual-Targeting Nanohybrid Protein Toxin Constructed by Intein-Mediated Site-Specific Ligation for Multistage Booster Delivery. Theranostics 2017, 7, 3489-3503. [CrossRef] [PubMed] 
145. Chang, Y.; Yao, S.; Chen, Y.; Huang, J.; Wu, A.; Zhang, M.; Xu, F.; Li, F.; Huang, Y. Genetically-engineered protein prodruglike nanoconjugates for tumor-targeting biomimetic delivery via a SHEATH strategy. Nanoscale 2019, 11, 611-621. [CrossRef] [PubMed]

146. Chen, Y.; Zhang, M.; Jin, H.; Tang, Y.; Wang, H.; Xu, Q.; Li, Y.; Li, F.; Huang, Y. Intein-mediated site-specific synthesis of tumortargeting protein delivery system: Turning PEG dilemma into prodrug-like feature. Biomaterials 2017, 116, 57-68. [CrossRef]

147. Wu, A.; Chen, Y.; Wang, H.; Chang, Y.; Zhang, M.; Zhao, P.; Tang, Y.; Xu, Q.; Zhu, Z.; Cao, Y.; et al. Genetically-engineered "all-in-one" vaccine platform for cancer immunotherapy. Acta Pharm. Sin. B 2021, 11, 3622-3635. [CrossRef] [PubMed] 